\title{
12 Churches and COVID-19 in Botswana
}

\author{
Tshenolo J. Madigele and James N. Amanze
}

\section{Introduction and background}

COVID-19 pandemic is a contagious disease that is also known as corona virus. It is caused by the SARS-CoV2 virus. The virus was first identified in Wuhan, China in 2019. From there the virus spread across the world. The first cases of COVID-19 to be reported in Botswana on 30 March 2020 were three. As of 1 June 2020, there have been 35 confirmed cases and one death (Worldometers, 2020). On 31 March, President Dr Mokgweetsi Eric Masisi of Botswana declared a 28-day State of Public Emergency in order to curb the spread of the COVID-19 pandemic. The legislators later approved an extension of State of Public Emergency to last up to six months (Mmegi Online, 30/03/2020). Extreme social distancing or the lockdown started on 2 April 2020 in Botswana.

During the lockdown period, people in Botswana were expected to stay home except for essential services such as going for medical care, pharmacies, buying groceries, petrol and collection of social grants during certain hours only. Thus religious, educational and social activities were suspended. People that violated lockdown rules could be imprisoned for a period lasting not more than two months or would be asked to pay a fine (Gazette, 2020a). The move towards extreme social distancing and its restrictions were influenced by the effects of the virus in all aspects of human existence. The virus is attacking humans, economy, social and spiritual aspects. It is more than a health crisis. It has been declared a pandemic by the World Health Organization as it is affecting societies at their core (WHO, 2020).

COVID-19 affects all segments of the population, it does not exclude anybody. However, people who are mostly affected are those in vulnerable positions such as the poor, elderly, unemployed youth, people with disabilities, some businesspeople, women and children. Mmegi Newspaper reports that Botswana has a population of 2.26 million. Of these, women are 1.17 million while men are 1.09. These statistics show that there are more women in Botswana than men. Moreover, women dominate the informal sector at $88.1 \%$. The informal sector is identified as the activities of the poor. These people include those who work in hotels, restaurants and self-employed. Most

DOI: $10.4324 / 9781003241096-12$ 
are working in unregulated sectors. Extreme social distancing took away many women's financial ability. During lockdown, many household helpers returned to their homes and many mothers were further faced with a duty of caregiving and increased chores as everybody was home on fulltime basis (Mmegi, 2020b).

Moreover, the newspaper reports that domestic and gender-based violence cases escalated during lockdown. Those included intimate partner femicide and attempted murders. It was difficult for women under lockdown restrictions to seek for help. Hence, many stayed home with their perpetrators who were mainly primary earners in the family. Social workers were not able to deal with psycho-social impacts of COVID-19 since their focus was mainly on the role of food provision (Mmegi, 2020a).

Meanwhile, UNICEF on the 15th of April 2020 reported concerning alarming numbers of children who had been raped since the beginning of COVID-19 lockdown in Botswana. Twenty-two rape cases of children aged between 2 and 13 were reported within 14 days of extreme social distancing. It is further reported that rape and defilement offences during lockdown were committed by family members of the victims (UNICEF, 2020). Still on child rape and defilement, on April 14, Yarona FM News reported that Deputy Police Commissioner Dinah Marathe shared that they recorded 23 defilement cases and 22 rape cases of children under 13 years of age. The Commissioner did not rule out the possibility of more incidents of this nature as it mainly involves family members hence secrecy at the expense of children (Yarona FM News, 2020). The above reports show that confinement is a nightmare for children in Botswana hence the need for protection during and post COVID-19 era.

The era of extreme social distancing has not only denied children's sexual and reproductive rights, and it has also denied them the right to nutrition. Schools in Botswana do not only serve as education institutions, and they are also places that provide food and nutrition for the survival of many children. The economic hit has direct effect on families with larger membership. Therefore, there is a need of intervention (Sunday Standard, 27th April 2020).

The San community had also been devastated by the COVID-19 pandemic. The community is communal in nature and sharing of food and other good is a cultural value and norm. In other words, communalism is a necessity. COVID-19 had further exacerbated economic loss as those that had been retrenched now rely on monthly government food ration that is not enough for larger households. Health information and advice issued by the government is mainly in Setswana. This fails to take into account other local languages and the cultural specifications and the conditions under which the San community live (Naturaljustice.org, May 21st, 2020).

At the time of writing this chapter, Botswana had recorded one death case due to the pandemic. This victim was an elderly woman who was 79 years old. Meanwhile, information moving around on different media platforms in Botswana reveals that elderly people are among the most vulnerable groups 
in the COVID-19 pandemic especially if they are physically unfit and suffering from respiratory illnesses, heart disease or high blood pressure. More news reveal that the death rate of COVID-19 increases for those aged 70 or higher (Garg et al. 2020; Promislow et al. 2020). There is currently no information on effects of COVID-19 on the elderly people in Botswana. However, literature shows that extreme social distancing cut-off extended family and traditional community support systems that older persons depend on for survival (Promislow et al. 2020). Most of the elderly live in rural areas where health care systems, sources of income and access to information are poor (Promislow et al. 2020; Volpato et al. 2020). Changes to operational infrastructures including transport systems to support the curbing of the pandemic put older persons at increased health risks. It has been revealed that elderly people experience ageism, discrimination, neglect abuse and violence at family, community and society levels (Ingstad et al. 1992; Mudiare, 2013). However, their challenges received no attention during lockdown.

Studies further reveal that, because of their frailty, elderly people depend on their families and other caregivers for care and in the process, they are abused (Ingstad et al. 1992; Mudiare, 2013). Also, in the absence of institutional care, adult children who are too busy to take care of their parents hire caregivers who also maltreat them. Unfortunately, the elderly are unable to challenge their abusers and have no way of reporting their abuse, and so many suffer in silence (Mudiare, 2013). COVID-19 had obviously aggravated the situation of the elderly but there is currently nothing on the awareness on the situation of the elderly, neither is there tailor-made information on COVID-19 to older persons in rural areas using community structures and local languages so that older persons are fully informed about the disease, prevention, protection and treatment measures.

The youth of ages 15-24 are among people who are vulnerable to COVID-19 pandemic. Youth unemployment had always been a concern in Botswana as it leads to social ills such as drug and alcohol abuse, poverty and crime (Mogomotsi \& Madigele, 2017). Statistics Botswana 2018 reveals that national youth unemployment rate in Botswana was $25.1 \%$ in the year 2016. The numbers escalated to $37.52 \%$ in 2019 (Statistics Botswana, 2019). Due to COVID-19, the unemployed youth are likely to be among those whose jobs have come to an end in formal and informal employment as a result of the pandemic. After just less than a month of restrictive measures, most of the youth are struggling to survive, meet their basic needs and adhere to orders and guidelines set up by the government of Botswana. Some were brutally assaulted by members of Botswana's armed forces (the police and soldiers), while on the streets. However, the president of Botswana, Dr Mokgweetsi Eric Masisi warned the country's law enforcers not to abuse people during the lockdown, as the nation fights COVID-19 pandemic (The Botswana Gazette, April 2020b).

Mmegi Newspaper, article titled, "Possible Economic Impact of COVID-19 on Botswana" reports that currently, unemployment stands at $29 \%$. In this 
report, $57 \%$ are employed in the formal sector while $43 \%$ are in the informal sector (Mmegi, 2020a). The pandemic has hit hard the informal sector, small business owners and the unemployed. The issue is likely to cause social unrest if not attended to (Mmegi, 2020a).

It is worth noting that the government of Botswana had established a COVID-19 relief fund with a 2 billion Pula to finance wage subsidy amounting to $50 \%$ of salaries of affected businesses. The government subsidy ranges from 1,000 to 2,500 pula for a period of three months (Mmegi, 2020). This means that those left out are from informal sectors, Non-profit organizations and companies which are not registered with Botswana Unified Revenue Services (BURS). Botswana Council of Churches (BCC) Secretary General Rev Gabriel Tsuaneng says the church is amongst the hardest hit institutions by the Coronavirus (COVID-19) pandemic in the country. There is currently no solution on the economic status of pastors and church employees during this period (Gazette, 2020a). Therefore, the Church remains a victim of COVID-19 pandemic and extreme social distancing. The cancelling of religious gatherings might have negative impact on the mental health of people. Religious gatherings contribute to the healthy sense of community, tradition and national identity (Gazette, 2020b). During these times, many people are being fired and that is a risk factor for the development of mental health issues. Religious leaders are equally facing mental health issues as

The Church relies on offerings and tithes, and since there are no church services, things are now very difficult. Pastors' welfare has significantly changed as a result of the outbreak of the pandemic and also since the extreme social distancing protocols were put into effect.

(Gazette, 2020a)

Moreover, if there are no offerings and tithes, congregations will not be able to provide basic needs to the poor.

This chapter provides an overview of how the religious fraternity in Botswana has responded to COVID-19 by identifying the strengths and challenges of these responses as well as outlining lessons learnt for the future in terms of the interface of epidemics, religion and politics.

\section{Method}

A qualitative research method was adopted to understand the impact of COVID-19 on Christian communities falling under three church organizations namely Evangelical Fellowship of Botswana (EFB), Botswana Council of Churches (BCC) and Organization of African Instituted Churches (OAIC). These organizations fall under the Botswana Network of Christian Communities (BONECO). Adopting a phenomenological design, a structured telephonic interview was used targeting 30 pastors from different 
congregations who fall under the umbrella BONECO. At least ten pastors from congregations that fall under each umbrella organization were interviewed. The interview comprised six questions:

1 Explain the impact of COVID-19 on you and your congregation and discuss adjustment you made in your congregation?

2 Do you have any diaconal programs prior or and during the pandemic? Discuss the adjustment you had to make because of COVID-19.

3 How have extreme social distancing affected your ministry?

4 Kindly share with us congregational written guidelines to address the above if you have them.

5 How are you reaching out to your congregants under COVID-19 restrictions?

6 Which methods of communication are you using to uplift people's spirits under realities of COVID-19?

A questionnaire was sent to 45 pastors who were requested to send their responses within a period of two weeks. Thirty questionnaires were sent back on time hence the number of participants is enough to gather valid information (Crouch \& McKenzie, 2006). The data collected were coded and thematized according to literature review findings and the interview questions. This chapter was also guided by the practical considerations and recommendations for religious leaders and faith-based communities in the context of COVID-19 from the World Health Organization's (WHO). On the 7th of April 2020, WHO came up with an interim guidance on how religious leaders, faith-based organizations, and faith communities can play a major role in saving lives and reducing illness related to COVID-19.

\section{Findings and discussion}

\section{COVID-19 fear, anxiety and panic}

Given the impact of COVID-19 on health, financial, social, religious, political and travel aspects, there is a likelihood of increasing anxiety, fear and panic. The rise of other infections such as flu might exacerbate more concern and panic. Moreover, ungoverned media coverage on COVID-19 that talk about this pandemic as unique and deadly has added more stress and panic. On the other hand, uncertainty, social isolation may contribute to stress and breakdown (Shigemura et al., 2020).

When deliberating on how the Church in Botswana managed to deal with the psychological, emotional and social impacts of the pandemic, most of the respondents maintained that they used technology such as videos, audio tapes, phones, social media to reach out to their congregants and the wider society. The Evangelical Lutheran Church in Botswana (ELCB) Ramotswa Congregation created a WhatsApp group for its members called 
"A Sermon" as a platform of sharing messages of hope during these difficult times (Interview with Deac. Bachomi, 2020).

The advantage of technology is that pastors managed to reach out to the wider society. Botswana national Television (BTV) recorded messages available online or handed to them by different churches and organizations such as Botswana Council of Churches (BCC). Even though the church could not measure the impact of media evangelism, people could hear the gospel with their families and people are being reached out without any possibility to gather. Those who do not have the internet and mass media orbit were encouraged to have household and family worship sessions.

A guide by the World Health Organization (WHO) outlines the critical role of religious leaders in disseminating accurate information, reducing fear and stigma and ensuring safe worship spaces and practices in the wake of COVID-19. As indicated, conspiracy theories that unsettled people were rampant and were coming from all angles including religious angles. What might have further caused confusion, anxiety, panic and stress were religious teaching that looked at COVID-19 as the end of the world, punishment from God or a tool of anti-Christ (Calys- Tagoe, 2020).

It is however part of human life to panic when people realize dangers which can threaten our lives. John 16: 33 says, “...fear not, I have overcome the world." Teachings such as these should liberate and strengthen people to develop responsible ways for dealing with the pandemic. People therefore need to hear words of hope and encouragement in order to deal with the fears that are caused by COVID-19. The Church should further reach out to those who are struggling to understand the meaning of life and questioning the existence of God in order to help them discover the meaning of their lives, and gain hope.

It is argued that religion is very important for COVID-19 health promotion. It contributes to better health and wellbeing (Hart \& Koenig, 2020; Kowalczyk et al., 2020). In that regard, religion should not be viewed as a problem but as an important part of the worldview and lifestyle of the people. It is associated with the enhancement of health and it is an essential coping mechanism during these stressful times of COVID-19. Religion could further be a wheel that drives behavioural change, disease management in all levels including the revision of policies that are not favourable to the people (Kowalczyk et al., 2020).

In this era forward, therefore, the church should deliver hope where there is no hope instead of aggravating hopelessness. Church bodies such as BCC, EFB, OAIC and the umbrella body BONECO should be encouraged to examine the information from their member churches before circulation. The Church could also work alongside other service providers and the Ministry of Health and Wellness to ensure that people receive accurate information. In their sermons and messages, they should counter and address misinformation and misleading teachings which aggravate pain and stress. Moreover, the Church could translate accurate information to the language that 
could be understood by their members. The WHO has provided guidance that could be replicated and shared on different faith platforms. Ministry of Health and Wellness in Botswana has websites and different information channels that could be accessed for guidance.

\section{COVID-19 and abuse of other persons}

According to the letter written by the Synod Chairman of the United Congregational Church in Southern Africa (UCCSA), COVID-19 has put stress on the ministry and mission of the denomination. It demands for strong support system, prayer circles, counselling networks and prayer. The Chairman encouraged members of the UCCSA to be each other's keepers during these trying times. He further advised that the doors of the Church should be open as isolation centres, accommodation for the homeless during lockdown. The Church was further advised to extend the psychosocial and spiritual support of the distressed members of our society (Global Ministries, 7th April 2020).

Moreover, Botswana Council of Churches (BCC) in collaboration with the Ministry of Nationality, Immigration and Gender Affairs Department in Botswana has called for all COVID-19 responses to include tactics to stop sexual and gender-based violence. BCC stated that services for survivors are harder to access during the lockdown. The Church and the whole religious sector were not regarded as essential during lockdown; therefore, it was not easy to go out promoting messages of gender justice and provide counselling and support services. The church was not able to address the pain and suffering of others because of different reasons such as lack of finances. One of the respondents cited Matthew 25:39-40 to prove that the church failed dismally to reach out to the needy during the lockdown. The text reads '.. when was it that we saw you sick or in prison and visited you?' And the king will answer them, 'Truly I tell you, just as you did it to one of the least of these who are members of my family, you did it to me.'

Different churches in Botswana had similarly extended their facilities and resources to the needy during these trying times. However, there is a general concern of inadequate infrastructure and health facilities, posing higher risks for the spread of the disease. There is also a concern on lack of funds to enable the setting up of facilities for hand washing, manufacturing and distributing face masks as well as other hygienic measures. The Church is therefore challenged to promote collaboration and coexistence with relevant service providers during the COVID-19 pandemic. Through its close contact with local realities, the Church could direct action through advocacy.

Collaboration between religious and medical communities has been described as a smart move in the response to COVID-19. Community centred care that includes all stakeholders such as religious leaders, social workers, 
psychologists and social scientist should be encouraged in order to promote holistic healing (Winiger, 2020).

The World Health Organization recommends the use of technology to maintain connection and support people who need pastoral care, smallgroup interactive prayers and other forms of accompaniment (WHO, 2020). The organization highlights the increase of gender-based violence under the restricted environment. The Church is encouraged to actively speak against violence against women, children and marginalized people. It is also encouraged to provide support and encourage the abused persons to seek for assistance.

Another important role of the Church highlighted by WHO is advocacy. The Church is not only expected to provide a supportive environment, and it is also expected to advocate for the rights of the vulnerable people such as the elderly, youth, women, children and the San community. The World Council of Churches issued a Statement on the dual pandemics of COVID-19 and sexual and gender-based violence on the 23rd of April 2020. In the statement, the Church is advised to look beyond the current crisis and address the root causes of sexual and gender-based violence rather than wishing for a return to "normal." The Church is called upon to promote justice and peace that ultimately reduce vulnerabilities for all (WCC, 2020).

\section{COVID-19 and grieving}

There is little knowledge about impacts of COVID- 19 related grieving on all those who had endured loss, but it is common knowledge that COVID-19 leave children orphaned and people without their loved ones everywhere including in Botswana. This adds to the abovementioned multiple stressors which are likely to contribute to mental health problems. "Grief is a normal reaction to loss. It is experienced as feelings and emotions, while it preoccupies the mind in the form of thought and worries" (UNICEF, 2002). This implies that grieving has to do with a process of accepting the reality that the relationship to a significant person is gone. People go through an intense sense of loss when a loved one dies. Louw (2008:560) advises that grieving people should be allowed to cry and talk about their grief as this will speed recovery. Unfortunately the nature of the pandemic and regulations that surround it could not make it possible for pastors to take people through the grieving process. However, if there is little or no social support, people may suffer depression. Their loss could be more heart-breaking if they had witnessed their loved going through pain and if they were not able to bury their loved ones.

People should therefore be empowered on grieving. More support groups who meet using different platforms should be formed to facilitate spiritual and religious coping and move through the grieve process towards healing. Individual counselling is also very essential during this time of need (Schoulte, 2011; Jeffreys, 2011). 


\section{Diaconia and COVID-19}

COVID-19 has affected all aspects of our lives; it has disrupted the socioeconomic, psycho-emotional and the spiritual aspects of life. In a context of inequalities, promotion of self-interest and profit making such as ours, human lives are likely to suffer. The Church is also a victim of such context but has generally been engaged in humanitarian or diaconal services. During lockdown, some churches made contacts with their members through phone calls, WhatsApp calls and messages and emails. They used these platforms to pray, share uplifting reflections and to reach out to the concerns of their parishioners. Members were encouraged to donate food, shelter, clothing and share resources with those that had been affected by the pandemic. Communality and solidarity were attributes or values that were encouraged among members. In a joint message, the World Council of Churches, World Communion of Reformed Churches, Lutheran World Federation, and Council of World Mission urged governments to bolster support for healthcare and social protection, the Church is called to advocate against ineffective and corrupt governance at national levels that has exacerbated the inability to support those who are most vulnerable to the pandemic (European Christian Environmental Network, 2020). Hence suffering is structural and addressing its root cause brings sustainable development.

However, the government of Botswana has made a national call to contribute funds (or in-kind) to the COVID-19 Relief Fund. Individuals, companies, organizations and churches are making contributions towards the fund in order to cushion the economic status of the affected. The Seventh-Day Adventist Church (SDA) has donated the sum of P200, 000.00 to the COVID-19 Relief Fund and thus encouraged its members "who are financially able to voluntarily support this government initiative over and above what the SDA Church as an entity has contributed," (Guardian, 2020). As indicated, this palliative approach to address the socio-economic impacts of the pandemic is not sustainable. A sustainable approach is the one that restores inequities and justice; that acknowledges the intrinsic interdependence of humanity and all aspects of human existence. Economic success, peace and tranquility can only prevail if people are treated well.

\section{The challenge to the church}

The idea of closing churches was not welcomed by some Christians during national lockdowns. According to lockdown regulations, a maximum number of 50 is expected to gather. This regulation was disregarded by some congregants who were constantly dispersed by the police officers (interview, 20/08/2020). In other instances, protesting campaigns were being organized. An "Open Churches" campaigns were brewing in some churches against the idea of the regulated number of the people gathering for worship. The campaigns were however silenced by the escalating numbers of the deaths 
that were COVID-19 related. The main argument behind those attempted protests was that as much as public transport and places selling liquor were in full operation, the Church should also be allowed to operate as normal; they wanted a waver in numbers of people who gather at Church to be lifted (interview, 20/08/2020).

The other argument posed was that the government of Botswana did not give the Church an ample opportunity to play their role especially in mobilizing their members to take part in relieving those who were financially affected by COVID-19. Although in some churches, congregants pledged some money towards that noble cause, other churches experienced dwindling financial contributions as their members were affected financially by the pandemic (interview, 22/08/2020).

In as much as preaching the gospel, caring for the poor and attacking injustices has been the role of the Church (Newbegin, 1960:911), the Church has been forced to belong to the private spaces; to belong to a digital mediated space that excludes the poor and vulnerable. These spaces have immensely impacted on the offerings. Not all could do online money transfers hence congregations are not able to provide for the needy during these trying times (interview, 20/08/2020).

Digital mediated platforms further exclude those who cannot access pastoral services because they cannot afford technological and internet devices. Furthermore, not all afford observing COVID-19 protocols such as social distancing and constant washing of hands with soap and clean water. For people who do not have the means to access clean water, soap and who are living in crowded spaces, it is near impossible to observe all COVID-19 protocols. The Church is therefore challenged to come up with new ways of reaching out to the poor in the context of COVID-19.

Notwithstanding, the Church was not even enabled to voice their concern when they saw the negligence of the economic needs of the poor people (interview, 22/08/2020). However, solidarity and liberation of the poor has always been the essence of being Church. The Church is looked upon as a moral compass, 'inspiring, transforming, life-giving work of the Holy Spirit' (Kim, 2009:30). The issue of poverty, injustices and inequalities are structural, and it affects the whole community, not a local church. Therefore, the Church during these times is forced to extend the services to all the people and address those structures that had long normalized pushing other people to the margins of the society. It is forced to be in solidarity with the poor through playing its transformative role (Kim, 2009:30).

\section{A challenge or an opportunity?}

In fact the Church in Greek is referred to as ekklesia which means "gathering" (Magezi, 2012:4). It refers to the gathered people rather than a physical building. In that manner therefore, it is the buildings of the Church that are constantly closed as per the precautionary measures of COVID-19, but the 
Church is never closed. It is rather unfortunate that the Church had confined itself in its walls when it is not supposed to be limited to a particular space. COVID-19 therefore has created an opportunity for the Church to re-evaluate its mission, mandate and further fully embrace its identity. Prior to COVID-19, the church has been unfaithful to its identity and calling.

Maybe the Church should start off by being contextual and adopt a culture of listening to people in their specific context and time towards societal change and transformation (Baron \& Maponya, 2020:3). Being missional entails portraying God's glory in a transformative way. A missional Church therefore should find alternative ways of thinking about the church and an alternative hermeneutic to read the Bible in context (Niemandt, 2012:8; 2019:3). It should further be present to all people in all circumstances.

Digital mediated communication platforms such as video calls, zoom, emails, WhatsApp, Facebook provide opportunities for ministries that are not confined by space and time. Sermons are not necessarily prepared only for Sundays but are also prepared daily for all to follow in their space, be it at home with their families, while driving or at work. People grow spiritually whenever and wherever they are. In this case, ministers are forced to be innovative and adopt practical ministerial skills that are relevant for ministry during the COVID-19 era. Therefore, even though virtual space that excludes the poor and vulnerable, it makes it possible for people to be reached in all corners of the globe. Being missional, relevant and contextual entails using any available tool to be present, active and transformative in all circumstances. It entails coming up with long-term strategies to address poverty and domestic violence; focusing its mission to the needy and exploring new ways of being church as we try to transition to the new normal.

There is an urgent need for material support, financial and logistic resources. There is further need for advocacy for human rights and equity. A crisis like this demands for collaboration between the Church and other stakeholders such as the Ministry of Health and Wellness and civic organizations in providing justice, education services and psycho-social care to all. Liberation theologies should engage with scientists and policy makers to ensure that the Church rediscovers its identity and calling which is transformative and restorative in nature.

\section{Conclusion and recommendations}

COVID-19 pandemic continues to ravage our social, religious and economic structures. Though being victim of the pandemic, not regarded as essential during this crisis, the Church is expected to be a part of finding long-term solutions. The visibility of the Church has become minimal during and after extreme social distancing. Other challenges such as domestic or gender-based violence and poverty were further aggravated by the lockdown. The Church focused more of its energies trying to maintain its visibility upon the suspension of physical and public gatherings. It has since 
succeeded hence Christians would continue to hear God's word in other ways. This means that the Church had opened itself to the paradigm shift. The only area that is lagging is advocacy for human rights and equity. When the economy is business not people based, more unrest is yet to come. Poverty is structural and should be dealt with amicably. Issues of abuse are also structural. Marginalization is deeply rooted in patriarchy, racism, ageism and corruption. Dealing with the structures that influence inequality may consequently bring sustainable long-term development.

\section{References}

Baron, E., \& Maponya, M.S. (2020). The recovery of the prophetic voice of the church: The adoption of a "missional church" imagination. Verbum et Ecclesia 41(1), a2077. https://doi.org/10.4102/ve.v41i1.2077.

Calys- Tagoe, J. (2020). Theological Reflections on the COVID-19. All African Conference of Churches (AACC-CETA), Kenya.

Crouch, M., \& McKenzie, H. (2006). The logic of small samples in interview-based qualitative research. Social Science Information 45(4), 18. doi:10.1177/ 0539018406069584.

European Christian Environmental Network. (2020). Retrieved from https:// www.oikoumene.org/en/press-centre/news/european-christian-environmentalnetwork-releases-assembly-statement on the 20/04/2020.

Garg, S.K.L., \& Whitaker, M., et al. (2020). Hospitalization rates and characteristics of patients hospitalized with laboratory-confirmed Coronavirus disease 2019COVID-NET, 14 states, March 1-30, 2020. Morbidity and Mortality Weekly Report 69: 458-464. doi: 10.15585/mmwr.mm6915e3.

Gazette. (2020a). Emergency Powers and COVID 19. Gaborone: The Botswana Gazette.

Gazette. (2020b). The Church Clashes with Gov't over COVID-19 Relief Fund. Gaborone: The Botswana Gazette.

Global Ministries. (2020). Pastoral Ministry in the Wake of COVID-19: A Message from UCCSA Synod of Botswana. Retrieved from, https://www.globalministries. org/pastoral_ministry_in_the_wake_of_covid_19_a_message_from_uccsa_ synod_of_botswana on the 28/05/2020

Guardian. (2020). Seventh-Day Adventist Church (SDA) has Donated the Sum of P200,000.00 to the COVID-19 Relief Fund. SDA. Gaborone: Guardian Newspaper.

Hart, C.W., \& Koenig, H.G. (2020). Religion and health during the COVID-19 Pandemic. Journal of Religion \& Health 59, 1141-1143. https://doi.org/10.1007/ s10943-020-01042-3.

Ingstad, B., Bruun, F., Sandberg, E., \& Tlou, S. (1992). Care for the elderly, care by the elderly: The role of elderly women in a changing Tswana society. Journal of Cross-Cultural Gerontology 7(4): 379-398.

Jeffreys, S. (2011). Helping Grieving People When Tears Are Not Enough: A Handbook for Care Providers. Series in Death, Dying, and Bereavement. New York: Brunner-Routledge.

Kim, K. (2009). Joining in with the Spirit: Connecting World Church and Local Mission. Epworth, London. 
Kowalczyk, O., Roszkowski, K., Montane, X. et al. (2020). Religion and faith perception in a pandemic of COVID-19. Journal of Religion \& Health 59, 2671-2677. https://doi.org/10.1007/s10943-020-01088-3.

Magezi, V. (2012). From periphery to the centre: Towards repositioning churches for Meaningful contribution to public health care. HTS Teologiese Studies/Theological Studies 68(2), a1312. https://doi.org/10.4102/hts.v68i2.131.

Mmegi. (2020a). COVID 19: Masisi Declares State of Emergency, 28-Day Lockdown. Gaborone: Mmegi Newspaper.

Mmegi. (2020b). Possible Economic Impact of COVID 19 on Botswana. Gaborone: Mmegi Newspaper.

Mogomotsi, G.E.J., Madigele, P.K., \& Chamberlain, J.M. (2017). A cursory discussion of policy alternatives for addressing youth unemployment in Botswana. Cogent Social Sciences 3(1), 455-469: 1356619. https://doi.org/10.1080/23311886.2017. 1356619.

Mudiare, P.E.U. (2013). Abuse of the aged in Nigeria: Elders also cry. American International Journal of Contemporary Research 3(9), 79-87.

Niemandt, C.J.P. (2012). Trends in missional ecclesiology. HTS Teologiese Studies/ Theological Studies 68(1), a1198. https://doi.org/10.4102/hts.v68i1.1198.

Promislow, D. (2020). A geroscience perspective on COVID-19 mortality [published online April 17, 2020]. Journals of Gerontology Series A Biological Sciences and Medical Sciences. doi:10.1093/gerona/glaa094

Schoulte, J.C. (2011). Bereavement among African American and Latino/a American. Journal of Mental Health Counseling 33(1), 11. 2.

Shigemura J, Ursano RJ, Morganstein JC, Kurosawa M, Benedek DM (2020). Public responses to the novel 2019 coronavirus (2019-nCoV) in Japan: Mental health consequences and target populations. Psychiatry and Clinical Neurosciences 74(4):281-282. doi: 10.1111/pcn.12988.

Statistics Botswana. (2019). Labour Statistics Report 2011, Statistics Botswana, Gaborone, Botswana.

Sunday Standard. (2020). WHO, UNICEF joins hands with Botswana as child rape continues to rise. Retrieved May 28, 2020, from http://www.sundaystandard.info/ who-unicef-joins-hands-botswana-child-rape-continues-rise.

UNICEF. (2020). COVID-19: Children at heightened risk of abuse, neglect, exploitation and violence amidst intensifying containment measures. Accessed at www. unicef.org. 22nd of May 2020.

Volpato, S., Landi, F., \& Antonelli-Incalzi, R.A. (2020). Frail health care system for an old population: Lesson from the COVID-19 outbreak in Italy [published online April 21, 2020]. Journals of Gerontology Series A Biological Sciences and Medical Sciences. doi: 10.1093/gerona/glaa087.

WCC. (2020). Statement on the dual pandemics of COVID-19 and sexual and genderbased violence. Retrieved from https://www.oikoumene.org/en/resources/documents/ wcc-programmes/women-and-men/statement-on-the-dual-pandemics-ofcovid-19-and-sexual-and-gender-based-violence/view.

WHO. (2020). Technical guidance \#1. Strengthening the health systems response to COVID-19. Copenhagen: WHO Regional Office for Europe. http://www. euro.who.int/__data/assets/pdf_file/0007/436354/strengtheninghealth-systemsresponse-COVID-19-technical-guidance-1.pdf, accessed 22 May 2020.

Winiger, F. (2020). "More than an intensive care phenomenon": Religious communities and the WHO guidelines for Ebola and Covid-19. Spiritual Care 9(3), 245-255. https://doi.org/10.1515/spircare-2020-0066. 
World Health Organization. Coronavirus disease (COVID-19) outbreak. Available from: https://www.who.int/emergencies/diseases/novel-coronavirus-2019 [cited May 25, 2020].

Worldometers. (2020). COVID-19 coronavirus pandemic. Available from: https:// www.worldometers.info/coronavirus/. Accessed 20 May 2020.

Yarona FM News. (2020). 